\section{談話室 (海外研究体験記)}

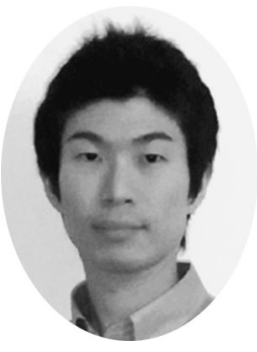

\section{ケンブリッジ大学での 研究生活}

\author{
杉 目 恒 志 \\ 早稲田大学高等研究所 \\ 区 169-8050 東京都新宿区 \\ 西早稲田 1-6-1
}

（2017 年 8 月 14 日受理）

\section{Research Life in the University of Cambridge}

Hisashi Sugime

Waseda Institute for Advanced Study, 1-6-1 Nishi Waseda, Shinjuku-ku, Tokyo 169-8050

(Received August 14, 2017)

\section{1.は じめに}

私が渡英したのは 2012 年 3 月のことである。 2010 年 3 月に博士課程を終了した後，ものづくりの現場を一度 は見てみたいと民間企業に就職していたため, アカデミ アの世界に戻ってくるきっかけにもなった。その後 2016 年 3 月まで 4 年間をケンブリッジ大学で過ごした ことを鑑みるとそれなりに大きな決断であった。ケンブ リッジ大学の人たちは，のんびりしているようでやると きはしっかりやるというスタイルであり，そんなイギリ ス生活を通して学んだことは大きかったと思う。

\section{2.イギリスでの経験}

\section{1 受け入れ先の決定}

いつか海外で研究者として働いてみたいと思っていた のもあり，ひとまず博士課程の指導教官に相談すること にした。すると学生時代のテーマをリードしているグル ープがアメリカとイギリスにあるのでコンタクトをとっ てみてはどうかといわれた。まずはイギリスのグループ にコンタクトをとってみることにしたが，このときなぜ こちらのグループを選んだかについては直感としかいい ようがない。それまでイギリスは英語の教科書に出てく る遠い未知の国であったため，なんとなく「面白そう」 と感じたのかもしれない。日本と同じように研究グルー

E-mail : sugime@aoni.waseda.jp
プにポスドクを雇えるかどうかはグループの主催者 (Principle Investigator, PI) がどれくらい研究予算を持っ ているかで決まる。ポスドクの給料や研究費がそこから 支払われるからであるが，これが学生の数にも当てはま るのが日本との違いである。グループの学生は基本的に 博士課程の院生で各自奨学金などを得て PI にコンタク 卜をとる。そして配属が内定してから英語の要件をはじ めとする大学の手続きなどをする。つまり，PI が基本 的にすべてを決めるのであり，学振や奨学金など外部か らお金を持ってこられれば受け入れは格段にスムーズに なる。私の場合はそのような外部の資金はまったくなか ったのだが，とりあえずコンタクトをとってみた。結 果，そのグループにはポジションがなかったのだが, PI の元指導教官である Prof. John Robertson のグループに 1 年半契約のポジションがあった。ケンブリッジ大学の大 学院に留学する場合は, 非常に高いレベルの英語要件が あるのに対し, 就労ビザの英語要件は実はそれほど高く はない。仕事をしていく上で当然英語を話さなければな らないが，それよりも研究能力が主な要件となる。これ については論文などの実績を蓄積しておくしかないであ ろう。初めての英語面接をスカイプでこなし, 何とか受 け入れてもらえることとなった。

\section{2 研究生活}

幸いにも行き先が決まり，イギリスでの研究室生活が スタートした。会社員時代の 2 年間のブランクがあった が，再びカーボンナノチューブ (carbon nanotube, CNT)

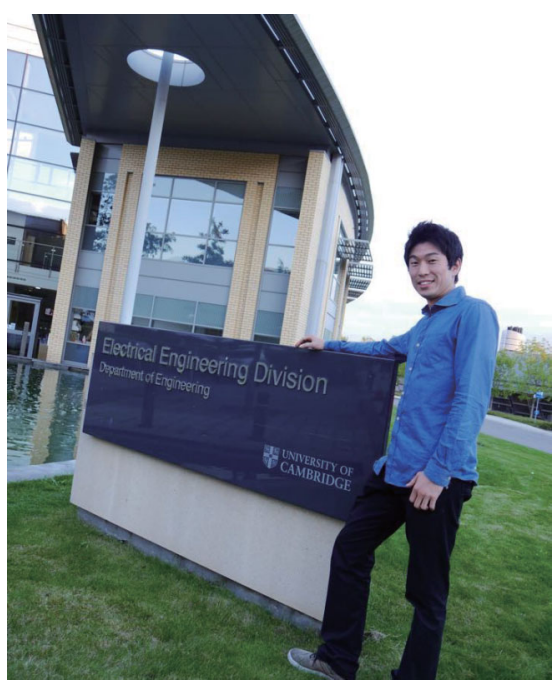

Fig. 1. (color online). The Center for Advanced Photonics and Electronics (CAPE). 


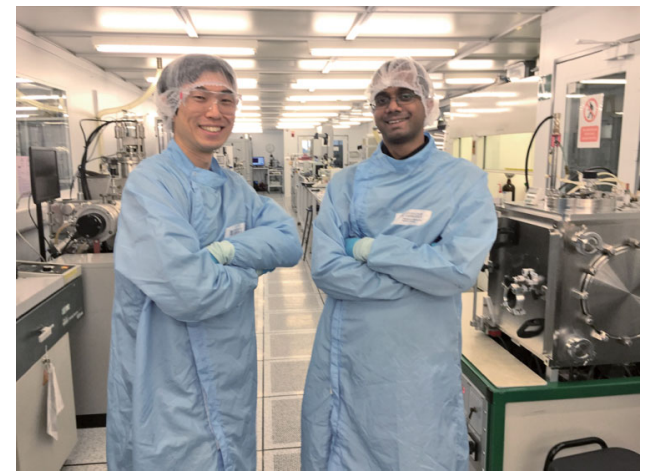

Fig. 2. (color online). Photo in the laboratory with a student.

の実験に打ち込む日々を過ごした。私が 4 年間お世話に なった場所はケンブリッジ市の西側の広大な土地にある Center for Advanced Photonics and Electronics (CAPE) と いうところである（Fig. 1)。複数のグループでクリーン ルームや装置などをシェアしており, 実験室内で別グル ープの人達と会話することも多かった（Fig. 2)。ビル内 の人たちは皆顔見知りで飲み会やイギリス独特の 15 時 からのティータイムでは話すことが多かった。CAPEに は学部生が抢らず博士課程の院生とポスドクがメインで あったのもあるが，イギリス国籍の人は 1-2 割程度で, 残りは様々な国籍のメンバーで構成されていた（Fig. 3)。このようにダイバーシテイを尊重するところがイギ リスの特徵であると思われる。英語が話せればどこの国 の出身であるかどうかはそれほど重視されず，それより も「あなたはどんな人？」という見られ方をしていたと 感じる。そんな多様性あふれる環境の中, 日本人は比較 的まじめに良く働いていたように思う。この勤勉さや細 部にこだわる姿勢はこれからも自信を持って世界にアピ ールしていって良いのではないかと考える。研究者間の つながりは学内だけにとどまらず, 地理的な要因からや はり特に EU 圈内の大学との共同研究は盛んであった。 短期間ドイッやイタリアに行って実験をしてくるなど, 日本でいうと県をまたぐくらいの感覚で国を行き来して いたように感じた。

基本的にのんびりしているが，メリハリをつけて効率 よく進めている人が多い中，私自身は比較的長時間実験 に明け暮れていた。その結果, 1 年目の中頃からは徐々 に面白い結果が出はじめ, 1 年が終わるころには世界最 高の質量密度を持つ CNT フォレストを成長させること に成功した1。この結果は Prof. Jhon Robertson にも認め てもらえたようで, 評価書や推薦書を書いてもらうとき などことあるごとに言及してくれていた。そのおかげも あり 3 年目からはJSPS の海外特別研究員に採用され

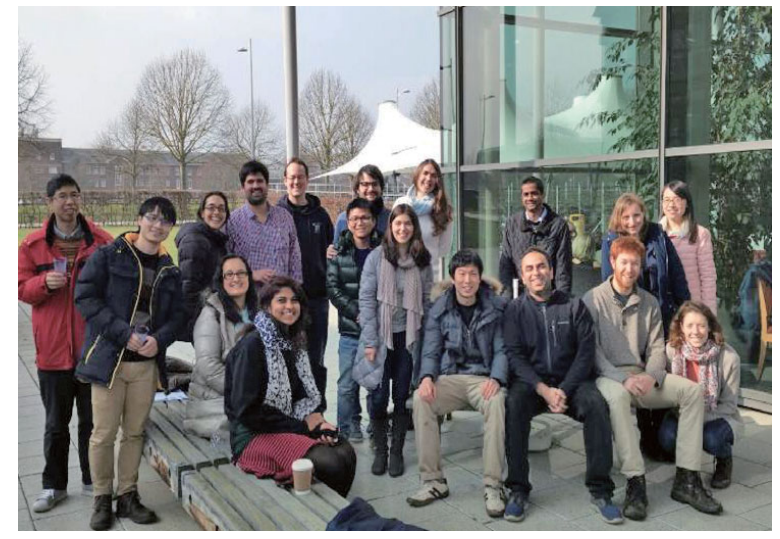

Fig. 3. (color online). Students and collegues working in the same building.

た。

\section{3 ケンブリッジでの日常生活}

街全体が大学という雲囲気のケンブリッジは歴史を感 じさせ, じっくりと研究に打ち込むにはとても良い環境 であった。日本の蒸し暑さと比較すると夏の気候は涼し く，そして昼が長いためとても快適な生活を送ることが できる。しかし一方で冬は日も短く, あっという間に暗 くなってしまう。週末などにロンドンに行けば，のんび りとしたケンブリッジとは打って変わった喧噪に触れる ことになる。旅行についてはユーロスターでロンドンか らブリュッセルやパリにも簡単に行け, 電車で 30 分の スタンステッド空港からは 2 時間以内のフライトでヨー ロッパ内であれば大体どこへでも行ける。私も滞在中に イギリス以外に十数か国は旅行し，ヨーロッパを満猰し た。

\section{3. と め}

あまり期待はせず起こることをすべて受け入れるのが 私のスタイルである。見知ら奻地での生活は色々大変 なことも多いが，学びも多く自分の可能性を広げるには もってこいの手段であろう。将来振り返ってみれば必ず 良い経験になるはずである。私自身も 4 年間の経験がこ れからの自分の研究生活にどのような影響を与えるかは わからないが, とてもためになる貴重な経験であったと 感じている。研究でわからないことができたときにも気 軽に聞ける仲間ができたことが何よりの財産であると感 じる。これから海外を目指す人には心よりエールを送り たい。最後に海外特別研究員に採用して頂いた日本学術 振興会に感謝申し上げます。

\section{文献}

1) H. Sugime : Appl. Phys. Lett. 103, 073116 (2013). 